\title{
O ATIVISMO JUDICIAL DO SUPREMO TRIBUNAL FEDERAL E A INTERFERÊNCIA NO PRINCÍPIO CONSTITUCIONAL DA SEPARAÇÃO DOS PODERES $^{1}$
}

THE JUDICIAL ACTIVISM OF THE SUPREME FEDERAL COURT AND INTERFERENCE WITH THE CONSTITUTIONAL PRINCIPLE OF THE SEPARATION OF POWERS

Matheus Henrique DIAS ${ }^{2}$

ISSUE DOI: 10.21207/2675-0104.2018.801

\begin{abstract}
RESUMO
O ativismo judicial é a constante interferência do Poder Judiciário em questões de competência do Poder Legislativo que por sua inércia e incompetência transfere sua função de modificar evolutivamente a sociedade efetivando seus direitos e garantias constitucionais para o Supremo Tribunal Federal, que se torna o único caminho viável para que os interesses da população sejam reconhecidos. Entretanto, ao interferir em outro Poder, o Supremo Tribunal Federal à mercê de abusos e exageros inconstitucionais que podem se tornar totalmente prejudicial à saúde da tripartição dos poderes, clausula pétrea de nossa Constituição Federal.

Palavras chave: Ativismo Judicial. Constituição Federal. Supremo Tribunal Federal.
\end{abstract}

\section{ABSTRACT}

Judicial activism is the constant interference of the Judiciary in matters of competence of the Legislative Power that by its inertia and incompetence transfers its function of evolutionarily changing the society, effecting its constitutional rights and guarantees to the Federal Supreme Court, which

\footnotetext{
${ }^{1} \mathrm{O}$ presente artigo sintetiza a monografia de conclusão da pesquisa, realizada para o Programa Interno de Bolsas de Iniciação Científica (PIBIC 2017-2018) da Faculdade de Direito de Franca (FDF), Franca/SP.

${ }^{2}$ Discente da Faculdade de Direito de Franca (FDF), Franca/SP. Bolsista do Programa Interno de Bolsas de Iniciação Científica (PIBIC 2017-2018).
} 
becomes the only viable path so that the interests of the population are recognized. However, by interfering with another Power, the Federal Supreme Court is at the mercy of unconstitutional abuses and exaggerations that may become totally detrimental to the health of the tripartite powers, a stalwart clause of our Federal Constitution.

Keywords: Judicial Activism. Federal Constitution. Federal Court of Justice.

\section{O ATIVISMO JUDICIAL: DOS ESTADOS UNIDOS DA AMÉRICA AO SUPREMO TRIBUNAL FEDERAL}

A sociedade não aceita mais a inércia do Poder Legislativo e do Poder Executivo na regulamentação de Leis, provocando o Poder Judiciário para resolver questões que envolvem desde a efetivação de política pública a de questões sociais, com isso, está consolidado o lado político do Supremo Tribunal Federal, órgão máximo de representação da justiça brasileira.

A Suprema Corte no Brasil, no exercício de suas atividades, está progredindo ao decorrer do tempo no número de casos em que é convocada para decidir sobre situações que a inserem em um contexto de figura de protagonista político e social.

Além disso, o amplo rol de legitimados a provocar sua atuação, segundo artigo 103 da Constituição Federal, cuja decisão é dotada de normatividade e em geral, com eficácia erga omnes, tem-se demonstrado sua proatividade em alcançar as normas constitucionais diante da inércia e/ou ignorância dos outros Poderes.

Por todo o exposto e nessa razão, o papel transformador do Supremo Tribunal Federal é traduzido no instituto do ativismo judicial.

Segundo Mayra Miarelli e Rogério Montai, entende-se por ativismo judicial ${ }^{3}$ :

O papel criativo dos tribunais ao trazerem uma contribuição nova para o direito, decidindo sobre a singularidade do caso concreto, formando o precedente jurisprudencial, antecipando-se, muitas vezes, à formulação da própria lei. Diante de necessidades novas em que a lei não se mostra suficiente ou diante de necessidades que forjam uma determinada interpretação do texto da lei, é o momento em que o esforço do intérprete faz-se sentir. Tem-se como ativismo judicial, portanto, a energia emanada dos tribunais no processo da criação do direito.

\footnotetext{
${ }^{3}$ MIARELLI, Mayra Marinho; DE LIMA, Rogério Montai. Ativismo judicial e a efetivação no Supremo Tribunal Federal. Sérgio Antonio Fabris Editor. 2012. p. 16.
} 
Em outras palavras e na explicação do termo o Ministro Luis Roberto Barroso assim leciona ${ }^{4}$ :

\begin{abstract}
"A ideia de ativismo judicial está associada a uma participação mais ampla e intensa do Judiciário na concretização dos valores e fins constitucionais, com maior interferência no espaço de atuação dos outros dois Poderes." Necessário esclarecer que o ativismo judicial é fenômeno jurídico do Direito dos Estados Unidos da América, na qual existe uma maior aproximação entre a atuação do juiz e a do legislador através do Direito common law.
\end{abstract}

Segundo estudiosos e juristas do assunto, o caso Marbury $\mathrm{x}$ Madison em 1803 é identificado como o início do ativismo judicial, sendo o caminho mais viável encontrado pela Suprema Corte americana para poder interpretar a Constituição de forma mais ampla e honesta em consonância aos preceitos fundamentais. caso $^{5}$ :

O Ministro Luis Roberto Barroso analisa as consequências do

\begin{abstract}
"Marbury v. Madison, portanto, foi à decisão que inaugurou o controle de constitucionalidade no constitucionalismo moderno, deixando assentado o princípio da supremacia da Constituição, da subordinação a ela de todos os Poderes estatais e da competência do poder Judiciário como interprete final, podendo invalidar os atos que lhe contravenham. Passou a ser lembrado universalmente como o precedente que assentou a prevalência dos valores permanentes das maiorias legislativas."
\end{abstract}

A primeira vez que o termo ativismo judicial foi citado no país criador se deu mais de cem anos depois, somente em 1907 com o jornalista Arthur Schlesinger Jr., em artigo publicado na revista Fortune sobre a atuação da Suprema Corte, sendo o texto direcionado a classificação do corpo de magistrados dividindo-os em de postura ativista e postura contida, no critério de interpretação jurídica a que eram submetidos.

José Canotilho, constitucionalista português, identifica duas correntes de interpretação constitucional americana que dá origem e difere os lados que formaram o ativismo judicial. Esclarece José Canotilho:

"As correntes interpretativas consideram que os juízes, ao interpretarem a constituição, devem limitar-se a captar o sentido dos preceitos expressos na constituição, ou, pelo menos nela

\footnotetext{
${ }^{4}$ BARROSO, Luís Roberto. O controle de Constitucionalidade no Direito Brasileiro. $5^{\circ}$ Edição. São Paulo: Saraiva, 2011. p. 365-6.

${ }^{5}$ BARROSO, Luís Roberto. O controle de Constitucionalidade no Direito Brasileiro. $5^{\circ}$ Edição. São Paulo: Saraiva, 2011. p. 32.
} 
claramente implícito, aponta como limites de competência interpretativa a textura semântica e a vontade do legislador. Estes limites são postulados pelo princípio democrático."

"De um modo geral, as posições não interpretativas defendem a possibilidade e a necessidade de os juízes invocarem e aplicarem valores e princípios substantivos - princípios da liberdade e da justiça - contra actos da responsabilidade do legislativo em desconformidade com o preceito da constituição. A mediação judicial concretizadora desses princípios é uma tarefa indeclinável dos juízes. ${ }^{7}$

Fica evidente nas correntes apontadas pelo jurista que a diferenciação se caracteriza na compreensão da constituição e da interpretação das normas constitucionais, enquanto os interpretativos não valem da admissão da prática do ativismo, os nãos interpretativos valem da máxima efetividade da norma constitucional colocando tudo submisso a real intenção da Lei.

Os nãos interpretativos estão em conformidade com a teoria da força normativa da Constituição de Konrad Hesse, que se refere à efetividade plena das normas contidas na Carta Magna de um Estado, e que para o jurista alemão, a norma constitucional deve ser revestida do mínimo possível de eficácia na vida social para não figurar como "letra morta em papel”.

Neste sentido, afirma Gerivaldo Alves Neiva ${ }^{8}$ :

"Esta compreensão de Hesse importa que a Constituição deverá imprimir ordem e conformação à realidade política e social, determinando e ao mesmo tempo sendo determinada, condicionadas, mas independentes"

\section{Luis Roberto Barroso ${ }^{7}$, também tem entendimento semelhante quando afirma que:}

"Atualmente, passou a ser premissa, do caráter vinculativo e
obrigatório de suas disposições. Vale dizer: as normas
constitucionais são dotadas de imperatividade, que é atributo de

${ }^{6}$ CANOTILHO, José Joaquim Gomes. Direito Constitucional e Teoria da Constituição. $7^{\circ}$ Edição. Coimbra: Almedina, 2003. p. 1197.

${ }^{7}$ CANOTILHO, José Joaquim Gomes. Direito Constitucional e Teoria da Constituição. $7^{\circ}$ Edição. Coimbra: Almedina, 2003. p. 1196.

${ }^{8}$ NEIVA, Gerivaldo Alves. Os fatores reais do poder e força normativa da Constituição. Articulações entre Konrad Hesse, Ferdinand Lassalle e Gramsci. Jus Navigandi, Teresina, ano 13, n. 1889, 2 set. 2008. Disponível em:<http://jus.uol.com.br/revista/texto/11664>. Acesso em: 10 maio. 2018. 
todas as normas jurídicas, e sua inobservância há de deflagrar os mecanismos próprios de coação, de cumprimento forçado".

Por essa razão, a posição do Poder Judiciário através do seu órgão de cúpula que a função de protetor da Constituição e dos valores e direitos fundamentais da sociedade e que diante da inércia, incapacidade e incompetência dos demais Poderes, tem que responder a sociedade que o representa, mesmo não sendo cargo eletivo, mas que com sua decisão que vincula a todos e alguns casos mesmo contra a vontade da maioria, faça valer o texto.

A identificação do ativismo judicial no Direito Brasileiro e de sua aplicação está na explicação do termo proferida por Luis Roberto Barroso':

“1) a aplicação direta da Constituição a situações não expressamente contempladas em seu texto e independentemente de manifestação do legislador ordinário; 2) a declaração de inconstitucionalidade de atos normativos emanados do legislador, com base em critérios menos rígidos que os de patente e ostensiva violação da Constituição; 3) a imposição de condutas ou de abstenções ao Poder Público, notadamente em matéria de políticas públicas."

No primeiro caso, sobre a aplicação direta da Constituição a situações não expressamente contempladas em seu texto e independentemente de manifestação do legislador ordinário, o jurista dá como exemplo, a fidelidade partidária.

O Supremo Tribunal Federal, em consonância aos princípios da moralidade e da impessoalidade declarou que a vaga do político eleito no Congresso Nacional pertence ao partido político, criando assim, um novo tipo constitucional de perda de mandato parlamentar, além das que se encontram expressamente previstas nos incisos do texto constitucional do artigo $55^{10}$.

\footnotetext{
${ }^{9}$ BARROSO, Luis Roberto. Ano do STF: Judicialização, ativismo e legitimidade democrática. Disponível em: http://www.conjur.com.br/2008-dez22/judicializacao_ativismo_legitimidade_democratica> Acesso em: 25 de Junho de 2018.

${ }^{10}$ BRASIL. CONSTITUIÇÃO. BRASÍLIA. SENADO FEDERAL. 1988.

Art. 55. Perderá o mandato o Deputado ou Senador:

I - que infringir qualquer das proibições estabelecidas no artigo anterior;

II - cujo procedimento for declarado incompatível com o decoro parlamentar;

III - que deixar de comparecer, em cada sessão legislativa, à terça parte das sessões ordinárias da Casa a que pertencer, salvo licença ou missão por esta autorizada;

IV - que perder ou tiver suspensos os direitos políticos;

V - quando o decretar a Justiça Eleitoral, nos casos previstos nesta Constituição;

VI - que sofrer condenação criminal em sentença transitada em julgado.”
} 
No julgamento da ADI 5081 que versa sobre a fidelidade partidária, o Supremo.

Tribunal Federal não alterou o texto constitucional, apenas extraiu da interpretação constitucional a ausência de qualquer vedação em norma constitucional ou infraconstitucional. Importante entendimento jurídico da Corte que trouxe uma mudança considerável na relação dos políticos com seus partidos e consequentemente com as ideologias que defendem.

Fica entendido, portanto, que a fidelidade partidária no campo do sistema proporcional (vereadores, deputados estaduais e deputados federais) é para assegurar o mínimo da vontade do eleitor ao depositar seu voto em um candidato que transmite e expõe uma ideologia na figura de seu partido.

Enquanto, no sistema majoritário (prefeito, governador, senador e presidente) este novo tipo de perda de mandato traz mais confiança ao eleitor de que o Executivo (maioria dos casos) respeitará a governança a que foi submetido durante toda a campanha eleitoral e a troca de posição partidária pode causar profundas mudanças na maneira de como se governa, haja vista que no Brasil o partido político devido às alianças realizadas deve para muitas instituições e pessoas que certamente com o poder nas mãos terão e sempre pagam de volta.

$\mathrm{Na}$ segunda aplicação do ativismo judicial brasileiro, temos a declaração de inconstitucionalidade de atos normativos emanados do legislador, com base em critérios menos rígidos que os de patente e ostensiva violação da Constituição, na qual o Ministro Luis Roberto Barroso identifica o caso de verticalização.

A Suprema Corte para barrar as novas regras sobre coligações eleitorais para aplicação na eleição que se realizaria em menos de um ano da aprovação da nova regra teve que declarar a inconstitucionalidade de norma constitucional, no julgamento da ADI 3685 . $^{11}$

Por esse motivo, a regra constitucional da anterioridade anual eleitoral do artigo 16 se tornou cláusula pétrea, ou seja, se insere de modo jurisprudencial aos institutos invioláveis de nossa Constituição ${ }^{12}$.

\footnotetext{
${ }^{11}$ BRASIL. Supremo Tribunal Federal. Ação Direta de Inconstitucionalidade $\mathbf{n}^{\mathbf{0}} 3685$ - Distrito Federal. Relator: Ministra Ellen Gracie. Brasília, 22/03/2006. http://redir.stf.jus.br/paginadorpub/paginador.jsp?docTP=AC\&docID=363397. Acesso em 20 de março de 2018.

${ }^{12}$ BRASIL. CONSTITUIÇÃO. BRASÍLIA. SENADO FEDERAL. 1988.

Art. 16. A lei que alterar o processo eleitoral entrará em vigor na data de sua publicação, não se aplicando à eleição que ocorra até um ano da data de sua vigência
} 
Fica comprovada a importância da interferência do Supremo Tribunal Federal em declarar que regras eleitorais devam ter no mínimo um tempo razoável, no caso um ano, para que a população possa entender melhor sobre o que está mudando e para impedir de forma petrificada de que os legisladores não irão criar e modificar regras eleitorais para se beneficiarem na eleição consequente.

$\mathrm{O}$ maior perigo que a ausência do artigo 16 e sua nova interpretação poderiam causar é a impossibilidade de renovação politica, principalmente nas casas do Legislativo que atualmente já contam com uma renovação inferior a $30 \%$.

A terceira e última maneira vista do ativismo judicial em nosso país é por meio da imposição de condutas ou de abstenções ao Poder Público, notadamente em matéria de políticas públicas, o célebre jurista exemplifica através da distribuição de medicamentos e na determinação de terapias mediante decisão judicial.

Para o Ministro que profere as ideias e identifica o exemplo nesta maneira de aplicação do ativismo, mesmo que não haja nenhuma decisão ou julgamento de fato no caso concreto sobre o assunto, mas é constante a aparição em processos que envolvam tanto a justiça federal como a estadual em litígios que os pacientes precisam de medicamentos e terapia que ainda estão em fase de experimentação cientifica e que não há comprovação técnica do assunto.

Em conformidade, pontua o autor ${ }^{13}$ :

"decisões que condenam a União, o Estado ou o Município - por
vezes, os três solidariamente - a custear medicamentos e terapias
que não constam das listas e protocolos do Ministério da Saúde ou
das Secretarias Estaduais e municipais. Em alguns casos, os
tratamentos exigidos são experimentais ou devem ser realizados no
exterior."

O ativismo judicial, neste terceiro caso de aplicação, aparenta ser a última esperança possível da sociedade em ter um direito social reconhecido, um problema da população especialmente carente que não possuem condições e diante do quadro econômico e político em que estamos não parece que um dia poderão adquirir. Não haveria outra forma de se conseguir experimentos não comprovados e fornecimento de medicamentos não testados cientificamente e sem a comprovação de institutos legais se não fosse pela interpretação liberal do Supremo

13 BARROSO, Luis Roberto. Neoconstitucionalismo e constitucionalização do Direito. Universidade de São Francisco (UFSCA). 
Tribunal Federal em trazer para a solução de um assunto em que não parece que entrará em pauta para ser discutido tão breve, em uma esfera remota.

O fenômeno do ativismo judicial é polêmico e crítico em todas as esferas do Direito, contudo é indiscutível aceitar seu lado positivo: o Judiciário está atendendo as demandas da sociedade que não puderam ser satisfeitas pelo Parlamento.

Outrora, o aspecto negativo é a exibição das dificuldades enfrentadas pelo Poder Legislativo inerte e do Executivo incompetente. Importante ressaltar que os julgados polêmicos do Supremo Tribunal Federal são midiáticos atraindo mais pessoas para assistirem o debate do assunto em pauta. As audiências públicas da Suprema Corte, com temas como o da descriminalização do aborto, realizadas nos dias 03 e 06 de agosto de 2018, trouxeram mais debate na mídia e na população do que as sessões legislativas que trataram do assunto.

\section{PRINCÍPIO CONSTITUCIONAL DA SEPARAÇÃO DOS PODERES}

O Poder advém do povo que é o verdadeiro detentor da pretensão organizacional do Estado. Alguns pensadores de épocas anteriores estudaram a melhor forma de organização do Poder, na qual se destacam as ideias de Aristóteles, John Locke e Montesquieu.

O primeiro a pensar na tripartição dos poderes foi Aristóteles, em sua obra mundialmente conhecida e a base do entendimento político, "A Política”. Na obra, Aristóteles fragmenta o poder em três funções estatais de: editar a lei, aplicar a lei e julgar a lei. Tal tripartição pode ser confundida com o atual modelo, entretanto Aristóteles concentrou todas as funções em apenas um órgão, um governante, o que causa desestabilidade de Poderes.

Mais tarde Locke inicia a divisão de funções em órgãos distintos, formando o Executivo, o Federativo e o Legislativo. Este último, para o pensador é o poder supremo e que os demais deveriam ser submetidos a ele.

Anos depois, surge Charles-Louis de Secondat, mais conhecido por Montesquieu, devido ao seu título de nobreza, e que foi um filósofo e político francês de formação iluminista, sendo um importante crítico da monarquia absolutista e do clero católico. Sua obra mais importante foi o tratado político “O Espírito das Leis" de 1748. 
Nesta obra Montesquieu defende um sistema de governo constitucional, a separação dos poderes, a preservação das liberdades civis, a manutenção da lei e o fim da escravidão.

Montesquieu foi o pensador revolucionário que apontou para a necessidade das funções serem exercidas por três órgãos diferentes e independentes para que pudessem legislar, executar e julgar a lei na forma mais coerente possível ${ }^{14}$ :

"Quando na mesma pessoa ou no mesmo corpo de magistratura, o
Poder Legislativo está reunido ao Poder Executivo, não existe
liberdade, pois pode-se temer que o mesmo monarca ou o mesmo
Senado apenas estabeleçam leis tirânicas para executá-las
tiranicamente. Não haverá também liberdade se o Poder de julgar
não estiver separado do Poder Legislativo e do Executivo. Se
estivesse ligado ao Poder Legislativo, o Poder sobre a vida e a
liberdade dos cidadãos seria arbitrário, pois o juiz seria legislador.
Se estivesse ligado ao Poder Executivo, o juiz poderia ter a força
de um opressor"

Destarte, é explícita para Montesquieu a indispensabilidade da separação das funções estatais de modo que o próprio poder limita o poder, partindo da premissa de que um único homem ou um órgão controlador passa a abusar do Poder que lhe é conferido.

Fundamental destacarmos que diante do contexto histórico da formulação da Teoria da Separação das Funções, momento de busca da superação de regimes autoritários, para Montesquieu o Judiciário teria de ser restrito para que a figura do juiz não se transformasse em legislador, haja vista o medo da época em permanecerem com qualquer tipo de arbitramento.

A chegada da Família Real Portuguesa em 1808 fugindo da tentativa de domínio de Napoleão Bonaparte trouxe alterações além da economia e da política, o Judiciário brasileiro recebeu a Casa de Suplicação, o primeiro órgão de cúpula do Poder Judiciário no Brasil.

A Casa de Suplicação foi criada por Alvará Régio e era composta por 23 ministros com sede no Rio de Janeiro, sua competência era encerrar definitivamente os litígios, que não precisavam ser necessariamente da esfera constitucional.

A Constituição de 1824, outorgada e imposta por Dom Pedro I previu a criação do Supremo Tribunal de Justiça e em 1828, o STJ substituiu a Casa de Suplicação, neste momento composta por 17

${ }^{14}$ MONTESQUIEU. Do Espírito das Leis. Coleção “Os Pensadores”. São Paulo: Nova Cultural. p. 201-2. 
ministros, sendo sua principal competência a mesma da cúpula anterior, julgar definitivamente todos os litígios, respeitando a Constituição Federal e fazendo a Lei ser aplicada.

Somente em 1891 com a Constituição promulgada que se introduziu o pensamento real de Poder Judiciária através de forte influência da doutrina norte americana que determinou que o órgão se tornasse protetor da Constituição de forma expressa em seu artigo 59, III, "a" e "b".

Em 1934, a Constituição Federal alterou o nome do órgão para Corte Suprema e diminuiu o número de ministros para 11, como é composto atualmente. A esta Carta Magna, destacamos a segurança jurídica por prever a fórmula do Senado, ou seja, a declaração de inconstitucionalidade de uma lei deveria ter maioria absoluta e introduziu o controle abstrato de inconstitucionalidade, garantindo definitivamente os efeitos das decisões da Corte.

Sobre a égide da Constituição de 1937, a cúpula foi neutralizada diante de um Estado não democrático, arbitrário e fascista que colocou o Executivo para preponderar sob os demais, sendo o Judiciário totalmente submisso, e, além disso, o texto constitucional previu a submissão do Judiciário ao Senado Federal que poderia suspender a execução de lei declarada inconstitucional pela Corte Suprema.

A Constituição de 1946 restaura o controle constitucional e o modelo previsto antes da Ditadura de Vargas.

A Constituição Federal de 1967 trouxe a novidade que personaliza o Supremo Tribunal Federal, a avocatória, instituto na qual submetia o julgamento pelo STF de qualquer causa que envolvesse direitos constitucionais em trâmite.

Por fim, chega a Constituição Federal de 1988 que determinou a transferência da figura do Supremo Tribunal Federal para além de um Tribunal Recursal, mas com a confirmação de uma Corte Constitucional.

O texto constitucional reservou ao órgão os artigos 101 a 103-B e de acordo com o mesmo, o Supremo Tribunal Federal deve ser composto de 11 ministros, com idade entre 35 anos e 65 anos, notável saber jurídico, reputação ilibada e ser brasileiro.

$\mathrm{O}$ atual Ministro da Corte Suprema, Alexandre de Moraes, sugere a urgente modificação desta investidura ${ }^{15}$ :

"Entre essas modificações, a exigência do notável saber jurídico deveria ser substituída pela presença de requisitos capacitários relacionados ou à qualificação profissional de bacharel em Direito,

${ }^{15}$ MORAES, Alexandre de. Direito Constitucional. 24 Edição: Atlas, 2009. p. 545. 
com exercício de no mínimo 10 anos de atividade profissional como advogado, membro do Ministério Público, magistrado, ou à qualificação de jurista, comprovada pelo titulo de doutor em Direito, devidamente reconhecido pelo Poder Público."

O erro na escolha passa além da necessidade de bacharelado em Direito, mas da ausência de mandato fixo para os Ministros, haja vista que após ser escolhido pelo Presidente da República e aprovado pelo Senado Federal por maioria absoluta, sendo que deveria ser maioria qualificada, o Ministro toma posse e goza de todas as garantias da magistratura, conforme artigo 95 do texto constitucional e passa a ter aposentadoria compulsória ao atingir os 70 anos de idade, de acordo com o artigo 93, inciso VI da $\mathrm{CF} / 88$.

As diversas propostas de alterações na escolha, como a da volatilidade do mandato, traria maior rotatividade entre os ministros e com isso garantiria a atualização da jurisprudência com pensamentos modernos e atuais.

\section{O ATIVISMO JUDICIAL DO SUPREMO TRIBUNAL FEDERAL E A INTERFERÊNCIA NO PRINCÍPIO CONSTITUCIONAL DA SEPARAÇÃO DOS PODERES}

A concretização constitucional deveria ser tarefa de todos os Poderes, entretanto o Poder Judiciário como já dito é o único empenhado em cumprir sua atividade a que foi destinado, enquanto os demais aparentam não estarem comprometidos com o alcance dos objetivos fundamentais instituídos na Constituição Federal para a ordem e progresso da nação.

Luís Roberto Barroso, em seu texto publicado no site Consultor Jurídico sobre o ativismo judicial e a legitimidade democrática, preleciona sobre o ativismo judicial e sua maneira de não execução, através de um Legislativo proativo ou realizador de suas tarefas ${ }^{16}$ :

"O binômio ativismo-autocontenção judicial está presente na maior parte dos países que adotam o modelo de supremas cortes ou tribunais constitucionais com competência para exercer o controle de constitucionalidade de leis e atos do Poder Público. O

\footnotetext{
${ }^{16}$ BARROSO, Luis Roberto. Ano do STF: Judicialização, ativismo e legitimidade democrática. Disponível em: http://www.conjur.com.br/2008-dez22/judicializacao_ativismo_legitimidade_democratica> Acesso em: 25 de Junho de 2018.
} 
movimento entre as duas posições costuma ser pendular e varia em função do grau de prestígio dos outros dois Poderes. No Brasil dos últimos anos, apesar de muitos vendavais, o Poder Executivo, titularizado pelo Presidente da República, desfruta de inegável popularidade. Salvo por questões ligadas ao uso excessivo de medidas provisórias e algumas poucas outras, é limitada a superposição entre Executivo e Judiciário. Não assim, porém, no que toca ao Congresso Nacional. Nos últimos anos, uma persistente crise de representatividade, legitimidade e funcionalidade no âmbito do Legislativo tem alimentado a expansão do Judiciário nessa direção, em nome da Constituição, com a prolação de decisões que suprem omissões e, por vezes, inovam na ordem jurídica, com caráter normativo geral."

O texto demonstra que o Legislativo em profundo declínio funcional e de ilegitimidade perante a sociedade transforma o ativismo judicial no fulcro da batalha judicante entre Legislativo inerte, Judiciário proativo e o Executivo midiático que mesmo incapaz de promover sua função completamente consegue a atenção da população, especialmente no período eleitoral.

Por essa razão, é nítida a omissão legislativa como a principal causa do ativismo judicial, a inércia em regular as situações plausíveis e possíveis de transformação de nossa sociedade através da aprovação e discussão de direitos e garantias, principalmente as fundamentais que são o ponto inicial para o processo da revolução social.

O principio da inafastabilidade da jurisdição é fundamental para se entender que o Judiciário é obrigado constitucionalmente a exercer o arbítrio de solução no caso concreto, ou seja, se for promovido deve haver uma resposta, mesmo que não seja clara ou bem fundamentada ${ }^{17}$.

"O Poder Judiciário, desde que haja plausibilidade de ameaça ao direito, é obrigado a efetivar o pedido de prestação judicial requerido pela parte de forma regular, pois a indeclinabilidade da prestação judicial é princípio básico que rege a jurisdição, uma vez que a toda violação de um direito responde uma ação correlativa, independentemente de lei especial que a outorgue".

O princípio coloca a máxima efetividade do Judiciário em ação, fazendo com que a omissão legislativa do Legislativo não seja eterna, tendo em vista que o órgão dotado de saber jurídico pode e deverá declarar mora de causa em que foi provocado devido à indiferença dos políticos legisladores.

17 CAMPOS, Corine. Direito de Ação: Princípio da Inafastabilidade da Jusridição. DireitoNet, 2003. Disponível em: https://www.direitonet.com.br/artigos/exibir/1067/Direito-de-AcaoPrincipio-da-Inafastabilidade-da-Jurisdicao> Acesso em 18 de Abril de 2018. 
Quando se declara a mora, o Legislativo deve se movimentar para regular a matéria, sendo considerado um puxão de orelha do Supremo Tribunal Federal para que se consiga prestar algum serviço à população na qual a omissão legislativa já está determinada, como exemplo tem o RE 851108.

O Ministro Celso de Mello nos explica sobre a mudança que o Supremo Tribunal Federal passou desde que entrou e o quanto o ativismo judicial auxiliou nessa transformação evolutiva e gradual ${ }^{18}$ :

Conjur - Comparado a agosto de 1989, quando o senhor tornouse ministro, o que mudou nos últimos dezessete anos no Supremo Tribunal Federal?

Celso de Mello - O STF, sob a atual Constituição, tomou consciência do alto relevo de seu papel institucional. Desenvolveu uma jurisprudência que lhe permite atuar como força moderadora no complexo jogo entre os poderes da República. O Supremo achase investido, mais do que nunca, de expressiva função constitucional que se projeta no plano das relações entre o Direito, a Política e a Economia.

Exerce uma função política e, pela interpretação das cláusulas constitucionais, reelabora seu significado, para permitir que a Constituição se ajuste às novas circunstâncias históricas e exigências sociais, dando-lhe, com isso, um sentido de permanente e de necessária atualidade. Essa função é plenamente compatível com o exercício da jurisdição constitucional. O desempenho desse importante encargo permite que o STF seja co-partícipe do processo de modernização do Estado brasileiro.

Conjur - Então, a evolução da doutrina e da interpretação da Constituição tem contribuído mais para aperfeiçoar as normas no Brasil do que a produção de novas leis?

Celso de Mello - A formulação legislativa no Brasil, lamentavelmente, nem sempre se reveste da necessária qualidade jurídica, o que é demonstrado não só pelo elevado número de ações diretas promovidas perante o Supremo Tribunal Federal, mas, sobretudo, pelas inúmeras decisões declaratórias de inconstitucionalidade de leis editadas pela União Federal e pelos Estados-membros."

18 FILHO, José Celso de Mello. Consultor Jurídico, 2006. Disponível em: https://www.conjur.com.br/2006-mar-15/juizes_papel_ativo_interpretacao_lei> Acesso em 18 de Abril de 2018. 
É importante ressaltar que, hoje, o Supremo desempenha um papel relevantíssimo no contexto de nosso processo institucional, estimulando-o muitas vezes à prática de ativismo judicial, notadamente na implementação de políticas públicas definidas pela própria Constituição que são lamentavelmente descumpridas, por injustificável inércia e desinteresse pelos órgãos estatais competentes.

O Supremo tem uma clara e nítida visão do processo constitucional. Isso lhe dá uma consciência maior e uma percepção mais expressiva do seu verdadeiro papel no desempenho da jurisdição constitucional.

Na medida em que o Legislativo se posiciona como ocioso e na necessidade de produzir leis com qualidade jurídica se torna inevitável à posição política do Tribunal Superior que ao perceber o apoio da população com as incontáveis decisões de inconstitucionalidade que é a prova mais cabal da incompetência legislativa que se torna o único Poder capaz de concretizar as politicas públicas suplicadas pela sociedade brasileira.

O Habeas Corpus $124.306^{19}$ do Estado do Rio de Janeiro trouxe a tona a discussão da descriminalização e inconstitucionalidade do tipo penal do aborto ao questionar a prisão preventiva de dois pacientes que mantinham clínica de aborto e que foram presos em flagrante.

Na primeira instância, houve a concessão da liberdade provisória aos acusados pelo $4^{\circ}$ Juizado Criminal de Duque de Caxias, entretanto o Ministério Público provocou recurso que foi reconhecido pelo juiz, momento em que a defesa teve de interpor ao Superior Tribunal de Justiça que não reconheceu a admissão do recurso e acabou por levar à Suprema Corte que julgaria e solucionaria o caso de forma definitiva e sem contradições.

Os pedidos da defesa se baseavam em preceitos processuais de boa conduta, de inexistência de antecedentes e a falta de necessidade de custodia cautelar e para o Supremo Tribunal Federal com a admissão do habeas corpus pelo relator Ministro Marco Aurélio houve o deferimento para afastar a custódia interposta.

Entretanto, o Habeas Corpus $124.306^{20}$ não foi julgado por mérito e extinto por inadequação processual, mas era necessário para a

\footnotetext{
${ }^{19}$ BRASIL. Supremo Tribunal Federal. Habeas Corpus $\mathbf{n}^{\mathbf{0}} 124306$ - Rio de Janeiro. Relator: Ministro Marco Aurélio. $\quad$ Brasília, http://redir.stf.jus.br/paginadorpub/paginador.jsp?docTP=TP\&docID=12580345. Acesso em 24 de março de 2018.

${ }^{20}$ BRASIL. Supremo Tribunal Federal. Habeas Corpus $\mathbf{n}^{\circ} 124306$ - Rio de Janeiro. Relator: Ministro Marco Aurélio. Brasília, 09/08/2016.
} 
sociedade um posicionamento da Corte sobre o assunto, uma posição constitucional sobre a tipificação do aborto no Brasil, haja vista ser de conhecimento jurídico a inconstitucionalidade dos artigos 124 a 126 do Código Penal Brasileiro.

Mas é a Arguição de Descumprimento de Preceito Fundamental $442^{21}$ promovida pelo Partido Socialismo e Liberdade que chega ao fulcro da problemática ao questionar a recepção da Constituição Federal dos artigos reservados ao aborto em um código realizado em $1940 \mathrm{com}$ incidência totalmente diversa na sociedade depois de quase um século, onde a etapa da civilização se encontra em outro nível ${ }^{22}$.

\footnotetext{
"Em democracias constitucionais laicas, isto é, naquelas em que o ordenamento jurídico neutro garante a liberdade de consciência e crença no marco do pluralismo razoável e nas quais não se professa nenhuma doutrina religiosa como oficial, como é o caso do Brasil, enfrentar a constitucionalidade do aborto significa fazer um questionamento legítimo sobre o justo"
}

Além disso, o partido alega que a permanência da criminalização é um modo que o Estado utiliza seu poder coercitivo para impedir o pluralismo razoável e em consonância com o pensamento do Ministro Luis Roberto Barroso em seu voto no Habeas Corpus 124.30653. O Estado deve proteger a mulher que quer ser mãe e deve proteger a mulher que não quer ser mãe, o Estado não tem o direito de escolher uma para proteger, sendo que ele existe para a proteção de todos

Os pedidos do Partido Socialismo e Liberdade (PSOL) são diversos, mas podemos identificar uma linha de pensamento em que o pilar da descriminalização é suspender definitivamente prisões em flagrantes, inquéritos policiais, processos judicias e decisões judiciais que são inconstitucionais por ferirem os direitos constitucionais de interrupção da gestação até a $12^{\circ}$ semana em que o feto não tem a formação de um sistema nervoso que o diferencia de um ser vivo para um ser humano, além disso,

http://redir.stf.jus.br/paginadorpub/paginador.jsp?docTP=TP\&docID=12580345. Acesso em 24 de março de 2018.

${ }^{21}$ BRASIL. Supremo Tribunal Federal. Arguição de Descumprimento de Preceito Fundamental $\mathbf{n}^{\mathbf{0}} 442$ - Distrito Federal. Relator: Ministra Rosa Weber. Brasília, 28/06/2018. http://stf.jus.br/portal/jurisprudencia/listarJurisprudencia.asp?s1=\%28\%28ADPF+442\%29\%29+NAO +S\%2EPRES\%2E\&base=baseMonocraticas\&url=http://tinyurl.com/y8rxg4nt. Acesso em 27 de março de 2018.

${ }_{22}$ Supremo Tribunal Federal. Notícias STF, 2017. Disponível em: http://www.stf.jus.br/portal/cms/verNoticiaDetalhe.asp?idConteudo=337860 Acesso em 15 de Agosto de 2018. 
da garantia de realizar procedimentos seguros que são inevitáveis aos profissionais da saúde que tanto clamam como as mulheres.

Ademais, se não bastasse à inconstitucionalidade do direito da mulher, existem inúmeras violações, como: violação à autonomia da mulher, violação do direito à integração física e psíquica, dos direitos sexuais e reprodutivos da mulher, bem como a violação à igualdade de gênero e a discriminação social e impacto desproporcional sobre as mulheres pobres e violação ao princípio da proporcionalidade, não sendo necessário destacarmos a violação ao principio da dignidade humana, por ser óbvio.

A ADPF ainda em discussão se baseia em outras ações provocadas ao Supremo Tribunal Federal, como a Ação Direta de Inconstitucionalidade $3510^{23}$ de 2008 , a ADPF $54^{24}$ de 2012 e o Habeas Corpus $124.306^{25}$ de 2016.

No momento de realização deste trabalho o Supremo Tribunal Federal está promovendo audiências públicas para discussão sobre o aborto que passaria a ser admitido plenamente e não só nas hipóteses legais como nos casos de estupro, fetos anencefálicos e risco de vida à gestante. Assim sendo caberia a mulher o momento de escolher ser mãe, a função mais importante do mundo.

As posições da Corte atualmente sobre a descriminalização pode ser colocada em uma grande maioria para o provimento do direito à vida pela mulher, entretanto a maioria não se manifesta publicamente com palavras diretas porque é uma questão delicada e que deve ser amplamente discutida e que para alguns não deveria ser assunto para a jurisprudência de uma Corte Suprema decidir, mas sim o Legislativo promover o processo legislativo de criação de uma norma transformadora da sociedade.

O fulcro da problemática coloca em questão a errônea abordagem sobre o tema, haja vista que ninguém é a favor do aborto e nem as mulheres que já praticaram são a favor do aborto, a pergunta correta para

\footnotetext{
${ }^{23}$ BRASIL. Supremo Tribunal Federal. Ação Direta de Inconstitucionalidade $\mathbf{n}^{\circ} 3510$ - Distrito Federal. Relator: Ministro Ayres Britto. Brasília, 29/05/2008. http://redir.stf.jus.br/paginadorpub/paginador.jsp?docTP=AC\&docID=611723. Acesso em 28 de março de 2018.

${ }^{24}$ BRASIL. Supremo Tribunal Federal. Arguição de Descumprimento de Preceito Fundamental $\mathbf{n}^{\mathbf{0}} 54$ - Distrito Federal. Relator: Ministro Marco Aurélio. Brasília, 12/04/2012. http://redir.stf.jus.br/paginadorpub/paginador.jsp?docTP=TP\&docID=3707334. Acesso em 21 de março de 2018.

${ }^{25}$ BRASIL. Supremo Tribunal Federal. Habeas Corpus $\mathbf{n}^{\circ} 124306$ - Rio de Janeiro. Relator: Ministro Marco Aurélio. $\quad$ Brasília, $\quad$ 09/08/2016. http://redir.stf.jus.br/paginadorpub/paginador.jsp?docTP=TP\&docID=12580345. Acesso em 24 de março de 2018.
} 
interpretação do assunto seria se somos a favor da criminalização do aborto, se fomos a favor de considerar uma mulher que promoveu seu livre arbítrio uma pessoa que mereça ir para a cadeia, haja vista ser essa a tipificação penal que criminaliza a liberdade dessas mulheres, mas que na realidade é bem diferente, posto que sejam poucas mulheres que são levadas para a penitenciária e as que são possuem uma característica fixa: mulheres, pobres e negras.

Tendo em vista que o aborto é um fato social e que vai continuar sendo praticado, seja com a tipificação penal ou não, o problema se encontra em como e onde ele vai ser executado, seja em uma cadeira de uma clínica clandestina com uma mulher branca e rica ou com um instrumento precário com uma mulher pobre e

negra.

A questão não é o aborto, mas sim as ideias retrógradas que não conseguem se libertar de seus dogmas em consenso a uma importância social de saúde pública, liberdade de expressão e autonomia corporal.

\section{CONSIDERAÇÕES FINAIS}

Parece-nos que o ativismo judicial é um erro. Contudo, ele pode ser um dos caminhos viáveis para a funcionalidade da pretensão social.

A população não pode mais ser alvo de uma espera indefinida e indeterminada de ações que dependam do Poder Legislativo. A sociedade tem conhecimento de que o Poder não está realizando seu papel e começará a promover as mudanças que ela necessita e aguarda impaciente.

O Poder Legislativo que tem a função legiferante acabou se transformando em instaurador de Comissões Parlamentares de Inquérito.

No Brasil, a estrutura do Poder se fragmenta em três divisões para que cada uma funcione com uma competência específica.

O Poder concentrado é utópico na atualidade e demanda que suas três divisões exerçam seus papéis, como no caso da omissão legislativa o equilíbrio está danificado e as divisões do Poder precisam intervir nesta outra divisão para que o Poder Legislativo não se torne completamente inerte e vazio.

O ativismo judicial, atualmente, se apresenta como uma alternativa para que o Poder Judiciário, interfira diretamente na atividade do Poder Legislativo, que demonstra estar paralisado, sendo incapaz, e 
ineficiente em razão de sua omissão e indiferente às necessidades da população.

O Poder Judiciário em alguns momentos tem se mostrado para a sociedade como um poder competente e compromissado com os seus interesses e por isso deslocou a credibilidade legislativa para sua credibilidade judicial.

Se o Poder Legislativo que deveria através do processo legislativo de elaboração de uma lei promover a efetivação dos direitos e garantias consideradas importantes não parece estar preocupado em realizar sua tarefa, a tutela passa para o processo judicial, na qual a lei dá lugar à jurisprudência, como a confirmação do desejo do povo.

Nessas condições, a lei que deveria entrar em vigor pelo sistema legislativo passa a vigorar na forma de jurisprudência devido a uma decisão de um tribunal superior. Assim sendo, o ativismo judicial pode ser considerado e como algo positivo, mas ele deveria ser submetido ao povo, que é o verdadeiro detentor do poder.

O Brasil em toda sua extensão é tudo que se encontra em nossas terras, além dos seres humanos, nossa fauna e nossa flora, ou seja, tudo que está presente em nosso território.

Para concentrarmos os problemas específicos do país dividimos em diversas partes, como a parte das mulheres, a parte dos homens, a parte dos homossexuais, a parte dos negros, a parte dos animais, a parte dos políticos sendo que todas as partes se juntam para formar um todo que é o Brasil, nossa nação.

Vale destacar que um mesmo indivíduo pode ser representante de quantas partes o acharem necessário, como exemplo: uma mulher, negra e advogada. Neste exemplo, temos três partes sociais que se juntam para formar o todo individual deste ser vivo.

A essas partes são atribuídos problemas específicos, de sua competência, como o aborto, o racismo, e a homofobia. Entretanto esses problemas específicos atingem o todo, porque se uma parte está sofrendo prejuízos, consequentemente o todo é atingido e também está sofrendo um prejuízo não de igual valor, mas de um prejuízo coletivo.

Por essa razão, o aborto não é apenas das mulheres, o racismo não é apenas dos negros, a homofobia não é apenas dos homossexuais. Os problemas são de todos. Os problemas são sociais.

O todo tem seu direito constitucional de liberdade de expressão, na qual ele pode opinar sobre um problema que é considerado seu também porque é um problema social. 
O todo tem seu dever constitucional de participar da elaboração da solução, porque a dialética é a forma como os indivíduos devem buscar a verdade real, sendo que uma parte sozinha não consegue ter forma pura de construir toda a solução para seu problema, sendo necessárias as ideias favoráveis e contraditórias para que juntas possam formar a melhor possível, a aquela que está em consonância e respeito com tudo.

A primeira vista, parece que a parte fica prejudicada com a inserção do todo na discussão de sua dificuldade, que antes de qualquer coisa é sua, $\mathrm{O}$ aborto é da mulher que o faz, o racismo é do cidadão que o sofre, a homofobia é do homossexual que tolera, mas nesta limitação está o ponto que determina o ativismo social que é exercido pelo ativismo judicial.

O todo não tem o direito de ser contrário completamente. O todo não tem direito de dizer não a um problema social. Ele pode opinar, pode falar o quanto quiser, mas não pode recusar e não admitir a existência do problema Ele deve entender que existe e deve ser integrante da solução porque no mínimo uma de suas partes carece de sua conclusão.

Em linhas prática, o aborto antes de ser um problema social, é um problema específico das mulheres e da saúde pública. Por isso, a população em geral tem o direito e o dever de discuti-lo, em todas as partes do todo, da religião ao jurídico. Entretanto, à mulher e à medicina ficam reservadas a maiores competências do assunto, ou seja, se a estas duas partes do todo estão firmes que o aborto necessita ser descriminalizado, as outras partes não podem devem respeitar e aceitar, procurando apenas a melhor solução para a problemática .

O caminho correto e natural para os contrários ao ativismo judicial seria a efetivação de garantias e direitos pelo Poder Legislativo que é incumbido de ser aquele que promoverá o processo legislativo para que vigore a solução de um problema social. Contudo, na prática sabe-se que isso não tem acontecido pela ausência de interesse e capacidade. Basta lembrar que temas importantes como a legalização da maconha e o aborto não forma discutidos até hoje pelo Poder legislativo .

Parece-nos que não é razoável, em algumas circunstâncias esperar por ações positivas ou soluções de problemas sociais de uma parte que é formada por políticos. Geralmente a estes apenas lhe interessam o poder do homem, que corrompe que faz o dinheiro ser submisso a tudo e a até a dignidade individual que resvala no desrespeito à população e à dignidade da pessoa humana. 
Em sede de conclusão, parece-nos que para a saúde da ordem e do progresso, a Tripartição dos Poderes tem que ser quebrada em alguns momentos, para que uma instituição independente venha a regular o equilíbrio dos Poderes.

O ativismo judicial não é a solução, mas o precedente para a pressão social.

\section{REFERÊNCIAS}

BRASIL. CONSTITUIÇÃO. BRASÍLIA. SENADO FEDERAL. 1988.

BRASIL. Supremo Tribunal Federal. Ação Direta de Inconstitucionalidade no 3685 - Distrito Federal. Relator: Ministra Ellen Gracie. Brasília, 22/03/2006.

http://redir.stf.jus.br/paginadorpub/paginador.jsp?docTP=AC\&docID=363397. Acesso em $20 \mathrm{de}$ março de 2018.

BRASIL. Supremo Tribunal Federal. Habeas Corpus $n^{\circ} 124306$ - Rio de Janeiro. Relator: Ministro Marco Aurélio. Brasília, 09/08/2016.

http://redir.stf.jus.br/paginadorpub/paginador.jsp?docTP=TP\&docID=12580345. Acesso em 24 de março de 2018.

BRASIL. Supremo Tribunal Federal. Arguição de Descumprimento de Preceito Fundamental n $^{\mathbf{0}} 442$ - Distrito Federal. Relator: Ministra Rosa Weber. Brasília, 28/06/2018.

http://stf.jus.br/portal/jurisprudencia/listarJurisprudencia.asp?s 1=\%28\%28ADPF+442\%29\%29+NAO +S\%2EPRES\%2E\&base=baseMonocraticas\&url=http://tinyurl.com/y8rxg4nt. Acesso em $27 \mathrm{de}$ março de 2018.

BRASIL. Supremo Tribunal Federal. Ação Direta de Inconstitucionalidade $\mathbf{n}^{0} 3510$ - Distrito Federal. Relator: Ministro Ayres Britto. Brasília, 29/05/2008.

http://redir.stf.jus.br/paginadorpub/paginador.jsp?docTP=AC\&docID=611723. Acesso em 28 de março de 2018.

BRASIL. Supremo Tribunal Federal. Arguição de Descumprimento de Preceito Fundamental no 54 - Distrito Federal. Relator: Ministro Marco Aurélio. Brasília, 12/04/2012.

http://redir.stf.jus.br/paginadorpub/paginador.jsp?docTP=TP\&docID=3707334. Acesso em $21 \mathrm{de}$ março de 2018.

BARROSO, Luís Roberto. O controle de Constitucionalidade no Direito Brasileiro. $5^{\circ}$ Edição. São Paulo: Saraiva, 2011.

BARROSO, Luis Roberto. Neoconstitucionalismo e constitucionalização do Direito. Universidade de São Francisco (UFSCA).

BARROSO, Luis Roberto. Ano do STF: Judicialização, ativismo e legitimidade democrática.

Disponível em: http://www.conjur.com.br/2008-dez-

22/judicializacao_ativismo_legitimidade_democratica> Acesso em: 25 de Junho de 2018. 
FILHO, José Celso de Mello. Consultor Jurídico, 2006. Disponível em:

https://www.conjur.com.br/2006-mar-15/juizes_papel_ativo_interpretacao_lei> Acesso em 18 de Abril de 2018.

MIARELLI, Mayra Marinho; DE LIMA, Rogério Montai. Ativismo judicial e a efetivação no Supremo Tribunal Federal. Sérgio Antonio Fabris Editor. 2012.

CANOTILHO, José Joaquim Gomes. Direito Constitucional e Teoria da Constituição. $7^{\circ}$ Edição. Coimbra: Almedina, 2003.

MONTESQUIEU. Do Espírito das Leis. Coleção “Os Pensadores”. São Paulo: Nova Cultural.

MORAES, Alexandre de. Direito Constitucional. 24 Edição: Atlas, 2009

NEIVA, Gerivaldo Alves. Os fatores reais do poder e força normativa da Constituição.

Articulações entre Konrad Hesse, Ferdinand Lassalle e Gramsci. Jus Navigandi, Teresina, ano 13, n. 1889, 2 set. 2008. Disponível em:<http://jus.uol.com.br/revista/texto/11664〉. Acesso em: 10 maio. 2018.

Supremo Tribunal Federal. Notícias STF, 2017. Disponível em: http://www.stf.jus.br/portal/cms/verNoticiaDetalhe.asp?idConteudo=337860 Acesso em 15 de Agosto de 2018. 